Abstracta Iranica Abstracta Iranica

Revue bibliographique pour le domaine irano-aryen

Volume 28 | 2007

Comptes rendus des publications de 2005

\title{
The Greek Wars. The Failure of Persia. Oxford, Oxford University Press, 2005, 316 p.
}

\section{Karin Mosig-Walburg}

\section{(2) OpenEdition}

1 Journals

\section{Édition électronique}

URL : http://journals.openedition.org/abstractairanica/15482

DOI : 10.4000/abstractairanica.15482

ISSN : 1961-960X

Éditeur :

CNRS (UMR 7528 Mondes iraniens et indiens), Éditions de l'IFRI

\section{Édition imprimée}

Date de publication : 15 mai 2007

ISSN : 0240-8910

\section{Référence électronique}

Karin Mosig-Walburg, "The Greek Wars. The Failure of Persia. Oxford, Oxford University Press, 2005,

316 p. ", Abstracta Iranica [En ligne], Volume 28 | 2007, document 74, mis en ligne le 18 septembre

2007, consulté le 25 septembre 2020. URL : http://journals.openedition.org/abstractairanica/15482 ;

DOI : https://doi.org/10.4000/abstractairanica.15482

Ce document a été généré automatiquement le 25 septembre 2020.

Tous droits réservés 


\title{
The Greek Wars. The Failure of Persia. Oxford, Oxford University Press, 2005, 316 p.
}

\author{
Karin Mosig-Walburg
}

1 Les relations gréco-persanes à partir de la sujétion des Grecs ioniens jusqu'à la fin de l'empire perse par Alexandre le Grand sont discutées par l'A., qui annonce dans son avant-propos qu'il veut éviter un point de vue hellénocentrique. Le livre comprend 10 chapitres et 9 appendices. Dans l'introduction l'A. aborde, en évaluant leur valeur historique, les sources littéraires. S'ensuivent 9 chapitres où l'histoire gréco-persane est abordée en ordre chronologique. Chacun des 9 appendices comprend la discussion d'un sujet special (par ex. 'The Themistocles decree'). Plusieurs points sont à relever. C'est d'abord l'attitude critique de l'A. envers le récit d'Hérodote - à mon avis trop critique - par ex. en ce qui concerne la révolte des Grecs ioniens. L'A. veut voir la cause de cette révolte, qui aurait eu bien des chances de réussir, dans un refus général de la domination perse par les Grecs ioniens. Mais il faut souligner que la domination perse n'avait pas été dure et que le développement de la révolte démontre bien qu'elle manquait de chances (voir le refus des Spartiates de soutenir les Ioniens). L'A. ne considère pas l'expédition perse de l'année 490 comme une expédition punitive contre les deux villes, Eretria et Athènes, qui avaient fait cause commune avec les Ioniens en attaquant Sardes ; il pense plutôt que les Perses auraient eu en 490 le plan de soumettre les Grecs européens. Cette position n'est pas tenable face à l'ampleur trop restreinte de la force militaire des Perses et le fait que c'était exclusivement une expédition navale. En ce qui concerne les raisons de l'échec de l'expédition de 480/79 (considérée comme une nouvelle tentative de soumettre les Grecs), l'A. constate que l'échec perse n'est pas dû à la vaillance des Grecs mais aux erreurs commises par les Perses eux-mêmes. 
INDEX

Thèmes : 3.2.2. Pré-Achéménides et Achéménides

\section{AUTEURS}

KARIN MOSIG-WALBURG

Université de Francfort 